\title{
Pedagogically and Professionally Ready: A Snapshot from Pre-Service Civic Education Teacher in Indonesia
}

\author{
Fauzi Abdillah $^{1}$, Yasnita ${ }^{1}$, Helen Ardhana Simanjuntak ${ }^{1}$ \\ abdillah@unj.ac.id, yasnita@unj.ac.id, helen ardhanasimanjuntak@unj.ac.id \\ ${ }^{1}$ Universitas Negeri Jakarta, Indonesia
}

\begin{abstract}
The teacher competences must be mastered by pre-service civic education students.The purpose of this study is to assess the pedagogic and professional competence of prospective civic education teachers in Indonesia. In this study, an attitude scale questionnaire is used to assess indicators of teacher pedagogic competence and professional competence. This study included 178 student-teacher candidates for undergraduate citizenship education from various regions throughout Indonesia. Questionnaires were distributed through social media of student organizations and a network of lecturers in the same field using an online Google form. The study's findings are summarized, and these teacher candidates are confident in their ability to boldly teach Pancasila values and morals. This study recommends bold efforts to increase students' abilities to develop students' potential, which, based on these data, has the lowest percentage score, reaching only 73 percent. Meanwhile, the assessment, evaluation of the process, and learning outcomes developed in developing Pancasila's character and morals have all been rated as 82 percent satisfactory. The percentage score is comparable to other items that assess students' ability to use information and communication technology to develop as teachers. This research implication leads to the education of future teachers at universities to provide adequate pedagogic skills to increase the potential of online assisted students.
\end{abstract}

Keywords: Civic Education Teacher, Student-teacher, teacher competences.

\section{Introduction}

Teacher competence is a frequently discussed topic in Indonesian education. Teacher competency tests (UKG) conducted on a routine basis reveal that teachers in Indonesia continue to earn an average score of 54 on a 100-point scale. This means that many regions have lower UKGs than the national average. Of course, this is a complex issue in and of itself. According to the Act, the competence of teachers in Indonesia consists of four components: Pedagogical Competence, Professional Competence, Social Competence, and Personal Competence. In the curricular dimension, a teacher's pedagogical and professional competence have a direct impact on student achievement [1].

Numerous stakeholders cast doubt on the effectiveness of online education in developing student character. This, of course, relates to the preparation and readiness of prospective teachers currently enrolled in undergraduate programs. However, in Indonesia, there are certain requirements for becoming a teacher. 
The government has focused on enhancing teacher quality by requiring teachers to complete portfolio-based assessments, but this is not considered an adequate method of assessing teacher competence. Proficiency in professionalism and learning processes, as well as students' attitudes, motivations, and interests in the teaching profession, all go hand in hand[2]. Teachers who are capable of managing learning, developing students' potential, and comprehending the participants' personalities are aided by a mastery of learning theories [3].

Utilizing an e-learning approach, specifically in Pancasila and Civic Education (PPKn), can provide teachers with the freedom to develop learning tools and students with the freedom to learn[5].

Civics subjects, with the ultimate goal of developing intelligent and ethical citizens [6], naturally require a teacher profile that is congruent with this[7]. Character education is frequently incorporated as a hidden curriculum component of civics education; however, this requires competent teachers. Thus, a process of developing and sustaining high-quality teachers who are relevant, competent, and committed to KDP implementation, particularly in the context of PJJ, is required. Thus, in order to understand the post-pandemic context in terms of teacher readiness for the process of implementing online learning and teaching, a multifaceted, personal, and contextual perspective is necessary[7].

Value and character education, which is the central concept in teaching Pancasila in Civics in the era of distance education, particularly online learning, is, of course, entangled in the phenomenon of learning loss. Additionally, some studies indicate that teachers rarely address systemic issues such as injustice and power relations when teaching diversity [8]. According to the researchers, deep and rooted issues must take a central role in the teaching of Pancasila as value education, which must be explored, developed, and applied immediately in light of contextual needs.

Additionally, the McKinsey Global Institute's most recent report states that the teaching profession will be dominated by online learning practices [9]. Welcoming this, of course, requires serious consideration of how teacher-producing universities educate and train prospective teachers and teachers to be capable of implementing distance education, particularly online-based education. Indeed, teachers can acquire knowledge about various facets of their professional practice through classroom instruction, school communities, professional development courses, online environments, and self-directed online learning [10]-[13].

Previous research on the theme of teacher education and distance education has addressed the issue of using learning materials (pedagogical tools) to foster creativity and intercultural competence [14], as well as the possibility of multicultural citizenship [15]. the incorporation of service learning into STEM scientific disciplines, which is still uncommon [16]. Education and training research to support teacher professional development through ongoing learning enrichment [17], online training that utilizes the personalization paradigm but still requires attention to diversity, specificity, and non-linearity in the process [18], and it is necessary to pay attention to teacher heterogeneity [19] with explains, analyzes, and discusses ethics, value education, and students' moral assumptions with a cultural lens [20].

In the context of Pancasila teaching, the issue of morality in teacher perceptions [21], teacherstudent relationships, and teacher cultural competence [22] should be investigated further. 


\section{Method}

This study was carried out online, with questionnaires distributed to undergraduate students enrolled in the Pancasila and Civics Education programs across Indonesia. Questionnaires were distributed via social media and chat messengers to student organizations at the study program level. The questionnaire was completed by 178 students. This research questionnaire was created using indicators of pedagogical and professional competence developed by the Ministry of Education and Culture of the Republic of Indonesia (Table 1). The paradigm that has been used to adapt these indicators is the approach of online learning. The Likert scale-based questionnaire has been validated for both validity and reliability. The collected data is then analyzed using descriptive tests to determine the possible profiles based on the data provided by the respondents.

Table 1 Questionnaire based on Pedagogic Competence and Instrument Teacher Competence

NO Component

1. Ability to map the characteristics of students from the physical, moral, social, cultural, emotional, and intellectual aspects online

2. Mastery of learning theory and principles of Civics learning that educates online

3. Mastery of PPKn curriculum development strategies that are oriented towards the development of students' Pancasila character and morals in the online realm

4. Ability to organize Civics learning activities that educate online

5. Ability to utilize information and communication technology for the benefit of online Civics learning

6. The ability to facilitate the development of the potential of students online to actualize their various potentials.

7. Mastery of effective, empathetic, and polite communication skills with students in the online realm

8. The ability to carry out assessments and evaluations of learning processes and outcomes that are oriented towards the development of Pancasila character and morals

9. Ability to utilize the results of assessment and evaluation for the benefit of Civics learning

10. Ability to take reflective action to improve the quality of learning

11. Mastery of material, structure, concept, and scientific mindset that supports the development of Pancasila character and morals in PPkn . subjects

12. Mastery of competency standards and basic competencies for PPKn subjects

13. Ability to develop Civics learning materials to develop students' Pancasila character and morals 
14. Ability to develop professionalism as a Civics teacher in a sustainable manner by taking reflective action

15. Ability to use information and communication technology to develop themselves as PPKn teachers

\section{Findings and Discussion}

In a one-week period, researchers conducted an online search using the self-assessment method for prospective Pancasila and Civic Education (PPKn) teachers. The pedagogical and professional competence of teachers in developing Pancasila character and morals is a critical dimension for determining how prepared students are to teach civics online.

Respondents completed a questionnaire using a Likerts scale with the following response options: Strongly Disagree (1), Disagree (2), Don't Know (3), Agree (4), and Strongly Agree (5). (5). The following table summarizes the data on their readiness in relation to their pedagogical and professional competence.

Table 2 Mapping of Pedagogic Competencies and Professional Competencies of Prospective PPKn Teachers

\begin{tabular}{|c|c|c|c|c|c|c|}
\hline \multirow{2}{*}{$\begin{array}{c}\text { Pedagogical and Professional } \\
\text { Competencies of Civics Teachers in } \\
\text { Developing Pancasila Character and } \\
\text { Morals Online }\end{array}$} & \multicolumn{5}{|c|}{ Response in Likert Scale } & \multirow{2}{*}{$\begin{array}{c}\text { Accumulated } \\
\text { Percentage } \\
(\%)\end{array}$} \\
\hline & 1 & 2 & 3 & 4 & 5 & \\
\hline \multirow{2}{*}{$\begin{array}{l}\text { I am able to map the characteristics of students } \\
\text { from the physical, moral, social, cultural, } \\
\text { emotional, and intellectual aspects online }\end{array}$} & 5 & 21 & 66 & 60 & 26 & \multirow{2}{*}{$\begin{array}{l}615 \\
(69 \%)\end{array}$} \\
\hline & (5) & (42) & (198) & $(240)$ & $(130)$ & \\
\hline \multirow{2}{*}{$\begin{array}{l}\text { I master learning theory and the principles of } \\
\text { civics learning that educate online }\end{array}$} & 2 & 11 & 69 & 72 & 24 & \multirow{2}{*}{$\begin{array}{l}639 \\
(72 \%)\end{array}$} \\
\hline & (2) & (22) & (207) & $(288)$ & $(120)$ & \\
\hline \multirow{2}{*}{$\begin{array}{l}\text { I master the strategy of developing the Civics } \\
\text { curriculum which is oriented towards the } \\
\text { development of the Pancasila character and } \\
\text { morals of students in the online realm }\end{array}$} & 1 & 14 & 61 & 75 & 27 & \multirow[b]{2}{*}{$\begin{array}{l}647 \\
(73 \%)\end{array}$} \\
\hline & (1) & (28) & (183) & $(300)$ & (135) & \\
\hline \multirow{2}{*}{$\begin{array}{l}\text { I am able to organize PPKn learning activities } \\
\text { that educate online }\end{array}$} & 1 & 5 & 47 & 87 & 38 & \multirow[b]{2}{*}{$\begin{array}{l}690 \\
(78 \%)\end{array}$} \\
\hline & (1) & (10) & (141) & $(348)$ & $(190)$ & \\
\hline \multirow{2}{*}{$\begin{array}{l}\text { I am able to use information and } \\
\text { communication technology for the benefit of } \\
\text { online Civics learning }\end{array}$} & 3 & 3 & 30 & 88 & 54 & \multirow[b]{2}{*}{$\begin{array}{l}721 \\
(81 \%)\end{array}$} \\
\hline & (3) & (6) & $(90)$ & $(352)$ & $(270)$ & \\
\hline \multirow{2}{*}{$\begin{array}{l}\text { I am able to facilitate the development of } \\
\text { students' potential online to actualize their } \\
\text { various potentials. }\end{array}$} & 3 & 11 & 63 & 72 & 29 & \multirow{2}{*}{$\begin{array}{l}647 \\
(73 \%)\end{array}$} \\
\hline & (3) & (22) & (189) & (288) & $(145)$ & \\
\hline
\end{tabular}




\begin{tabular}{|c|c|c|c|c|c|c|}
\hline \multirow{2}{*}{$\begin{array}{l}\text { I master the skills of communicating } \\
\text { effectively, empathically, and politely with } \\
\text { students in the online realm }\end{array}$} & 2 & 6 & 40 & 88 & 42 & \multirow{2}{*}{$\begin{array}{l}720 \\
(81 \%)\end{array}$} \\
\hline & (2) & (36) & (120) & (352) & $(210)$ & \\
\hline \multirow{2}{*}{$\begin{array}{l}\text { I am able to carry out assessments and } \\
\text { evaluations of learning processes and } \\
\text { outcomes that are oriented towards the } \\
\text { development of Pancasila character and morals }\end{array}$} & 1 & 6 & 40 & 85 & 46 & \multirow{2}{*}{$\begin{array}{l}727 \\
(82 \%)\end{array}$} \\
\hline & (1) & (36) & (120) & (340) & $(230)$ & \\
\hline \multirow{2}{*}{$\begin{array}{l}\text { I am able to take advantage of the results of the } \\
\text { assessment and evaluation for the benefit of } \\
\text { Civics learning }\end{array}$} & 2 & 5 & 36 & 89 & 46 & \multirow[b]{2}{*}{$\begin{array}{l}706 \\
(79 \%)\end{array}$} \\
\hline & (2) & (10) & (108) & (356) & (230) & \\
\hline \multirow{2}{*}{$\begin{array}{l}\text { I am able to take reflective action to improve } \\
\text { the quality of learning }\end{array}$} & 1 & 6 & 46 & 86 & 39 & \multirow[b]{2}{*}{$\begin{array}{l}714 \\
(80 \%)\end{array}$} \\
\hline & (1) & (36) & (138) & (344) & (195) & \\
\hline \multirow{2}{*}{$\begin{array}{l}\text { I master the material, structure, concept, and } \\
\text { scientific mindset that supports the } \\
\text { development of Pancasila character and morals } \\
\text { in PPKn subjects }\end{array}$} & 2 & 7 & 56 & 75 & 38 & \multirow{2}{*}{$\begin{array}{l}674 \\
(76 \%)\end{array}$} \\
\hline & (2) & (14) & (168) & (300) & (190) & \\
\hline \multirow{2}{*}{$\begin{array}{l}\text { I have mastered the competency standards and } \\
\text { basic competencies of Civics subjects }\end{array}$} & 1 & 6 & 53 & 84 & 34 & \multirow[b]{2}{*}{$\begin{array}{l}678 \\
(76 \%)\end{array}$} \\
\hline & (1) & (12) & (159) & (336) & (170) & \\
\hline \multirow{2}{*}{$\begin{array}{l}\text { I am able to develop Civics learning materials } \\
\text { to develop the students' Pancasila character } \\
\text { and morals }\end{array}$} & 1 & 5 & 42 & 91 & 39 & \multirow{2}{*}{$\begin{array}{l}696 \\
(78 \%)\end{array}$} \\
\hline & (1) & (10) & (126) & (364) & (195) & \\
\hline \multirow{2}{*}{$\begin{array}{l}\text { I am able to develop professionalism as a } \\
\text { Civics teacher in a sustainable manner by } \\
\text { taking reflective actions }\end{array}$} & 1 & 4 & 44 & 88 & 41 & \multirow{2}{*}{$\begin{array}{l}698 \\
(78 \%)\end{array}$} \\
\hline & (1) & (8) & (132) & (352) & (205) & \\
\hline \multirow{2}{*}{$\begin{array}{l}\text { I am able to use information and } \\
\text { communication technology to develop myself } \\
\text { as a PPKn teacher }\end{array}$} & 2 & 5 & 35 & 68 & 68 & \multirow[b]{2}{*}{$\begin{array}{l}729 \\
(82 \%)\end{array}$} \\
\hline & (2) & (10) & (105) & (272) & (340) & \\
\hline
\end{tabular}

According to the data presented above, the respondents' responses achieved an average percentage score in the range of 61 percent -80 percent (strong) and 81 percent -100 percent (very strong). Thus, based on the dimensions of their pedagogical and professional competencies in developing Pancasila character and morals, it can be concluded that respondents, namely PPKn students, are actually ready to conduct online learning. If these findings are consistent with previous studies[1], [3], [7], [9], the next step is to strengthen the existing efforts. Efforts to strengthen this are also consistent with other studies[7], indicating that readiness with elements of a multifaceted, personal, and contextual perspective can be implemented in a variety of ways with known benefits [10]-[13].

Meanwhile, some efforts must be made to improve students' ability to facilitate the development of students' potential online, which, according to data, has the lowest percentage score, which only reaches 73 percent. Meanwhile, the ability to conduct assessments, process evaluations, 
and learning outcomes aimed at the development of Pancasila's character and morals has reached a satisfactory level of 82 percent. The percentage score is comparable to other items that assess students' ability to use information and communication technology to grow as Civics teachers. This finding must undoubtedly be followed by cross-cultural skill enrichment in order to facilitate the existing cultural diversity [14], [15], [19], [20]. So that the digital space, which allows for more intense intercultural interaction, can be used to revitalize the spirit of education.

\section{Conclusion}

Prospective Civics teachers in Indonesia's various provinces are eager to begin their careers as educators. They confidently assume that they are mastered and skilled to practice the content of values and moral education in Civics. This confidence, however, must be academically supported by the study program in order to provide insight and experience related to digital competence and teaching competence in the digital space. This study undoubtedly has flaws because a more solid and accountable method is required to determine the readiness and skills with certainty. However, because it included respondents from various regions in Indonesia, this study was able to provide an initial understanding of the study.

\section{Acknowledgments}

This research was funded by the Faculty of Social Sciences, Universitas Negeri Jakarta with the Faculty Leading Research scheme in the 2021 fiscal year. This publication is one part of the research. The authors would also like to thank Abdul Rohman Tarigan, Chanisa Putri Tertia, and the Himnas PKn Network for assisting in distributing the questionnaires..

\section{References}

[1] T. Taniredja and M. Abduh, "Pedagogical, personality, social and professional competence in correlation with teachers' performance (Correlational study of junior high school teacher at SMPN 3 Purwokerto)," in The 2nd International Conference on Science, Technology, and Humanity, 2016, pp. 264-272.

[2] O. Jatiningsih, M. M. K. Sari, S. M. Habibah, R. N. Setyowati, M. T. Yani, and A. S. Adi, "Penguasaan kompetensi profesional guru oleh mahasiswa peserta praktik pengalaman pembelajaran," Jurnal Civics: Media Kajian Kewarganegaraan, vol. 15, no. 1 , pp. $37-44,2018$.

[3] A. Patabang and E. Murniarti, "Analisis Kompetensi Pedagogik Guru pada Pembelajaran Daring dimasa Pandemi Covid-19," EDUKATIF: JURNAL ILMU PENDIDIKAN, vol. 3, no. 4, pp. 1418-1427, 2021.

[4] F. M. Fawwazi, A. Abdulkarim, and K. Komalasari, "Teacher Competency in Civic Education Learning to Encounter Industrial Revolution 4.0 (Case Study at Sekolah Menengah Pertama 2 Bandung)," in Journal of International Conference Proceedings (JICP), 2020, vol. 3, no. 1, pp. 107-115.

[5] A. A. Wahab and D. Sapriya, "Teori dan Landasan Pendidikan Kewarganegaraan," Bandung: Alfabeta, 2011. 
[6] R. Scherer, S. K. Howard, J. Tondeur, and F. Siddiq, "Profiling teachers' readiness for online teaching and learning in higher education: Who's ready?," Computers in Human Behavior, vol. 118, May 2021, doi: 10.1016/j.chb.2020.106675.

[7] I. Sincer, S. Severiens, and M. Volman, "Teaching diversity in citizenship education: Context-related teacher understandings and practices," Teaching and Teacher Education, vol. 78, pp. 183-192, Feb. 2019, doi: 10.1016/j.tate.2018.11.015.

[8] S. Lund et al., "The future of work after COVID-19," 2021.

[9] H. Borko, "Professional Development and Teacher Learning: Mapping the Terrain," Educational Researcher, vol. 33, no. 8, Nov. 2004, doi: 10.3102/0013189X033008003.

[10] L. M. Desimone, "Improving Impact Studies of Teachers' Professional Development: Toward Better Conceptualizations and Measures," Educational Researcher, vol. 38, no. 3, Apr. 2009, doi: 10.3102/0013189X08331140.

[11] C.-P. Kao, Y.-T. Wu, and C.-C. Tsai, "Elementary school teachers' motivation toward web-based professional development, and the relationship with Internet self-efficacy and belief about web-based learning," Teaching and Teacher Education, vol. 27, no. 2, Feb. 2011, doi: 10.1016/j.tate.2010.09.010.

[12] P. Beach, "Self-directed online learning: A theoretical model for understanding elementary teachers' online learning experiences," Teaching and Teacher Education, vol. 61, pp. 60-72, Jan. 2017, doi: 10.1016/j.tate.2016.10.007.

[13] L. Titarenko and C. B. Little, "International Cross-Cultural Online Learning and Teaching: Effective Tools and Approaches," American Journal of Distance Education, vol. 31, no. 2, pp. 112-127, Apr. 2017, doi: 10.1080/08923647.2017.1306767.

[14] A. J. Castro, "The role of teacher education in preparing teachers for critical multicultural citizenship," Journal of Social Studies Research, vol. 38, no. 4, pp. 189203, 2014, doi: 10.1016/j.jssr.2014.02.006.

[15] E. Faulconer, "eService-Learning: A Decade of Research in Undergraduate Online Service-learning," American Journal of Distance Education, 2020, doi: 10.1080/08923647.2020.1849941.

[16] L. Stoetzel and S. Shedrow, "Coaching our coaches: How online learning can address the gap in preparing K-12 instructional coaches," Teaching and Teacher Education, vol. 88, Feb. 2020, doi: 10.1016/j.tate.2019.102959.

[17] M. M. Yurkofsky, S. Blum-Smith, and K. Brennan, "Expanding outcomes: Exploring varied conceptions of teacher learning in an online professional development experience," Teaching and Teacher Education, vol. 82, pp. 1-13, Jun. 2019, doi: 10.1016/j.tate.2019.03.002.

[18] F. Reichert and J. Torney-Purta, "A cross-national comparison of teachers' beliefs about the aims of civic education in 12 countries: A person-centered analysis," Teaching and Teacher Education, vol. 77, pp. 112-125, Jan. 2019, doi: 10.1016/j.tate.2018.09.005.

[19] R. Thornberg and E. Oğuz, "Moral and citizenship educational goals in values education: A cross-cultural study of Swedish and Turkish student teachers' preferences," Teaching and Teacher Education, vol. 55, pp. 110-121, Apr. 2016, doi: 10.1016/j.tate.2016.01.002.

[20] W. Ye and W. W. Law, "Pre-service teachers' perceptions of teacher morality in China," Teaching and Teacher Education, vol. 86, Nov. 2019, doi: 10.1016/j.tate.2019.102876.

[21] N. Pantić and T. Wubbels, "Teachers' moral values and their interpersonal relationships with students and cultural competence," Teaching and Teacher Education, vol. 28, no. 3, pp. 451-460, Apr. 2012, doi: 10.1016/j.tate.2011.11.011. 